\title{
TO EVALUATE THE RELATIONSHIP BETWEEN IRON DEFICIENCY AND FEBRILE SEIZURES
}

\author{
Pinnaka Subbarao1, Puttagunta Sree Apoorva2, Padmasani Venkat Ramanan ${ }^{3}$
}

${ }_{1}^{1}$ Assistant Professor, Department of Paediatrics, Sri Ramachandra Institute of Higher Education and Research Institute, Chennai, Tamilnadu, India.

${ }^{2}$ Resident, Department of Paediatrics, Sri Ramachandra Institute of Higher Education and Research Institute, Chennai, Tamilnadu, India.

3Professor, Department of Paediatrics, Sri Ramachandra Institute of Higher Education and Research Institute, Chennai, Tamilnadu, India.

\section{BACKGROUND}

ABSTRACT

Febrile seizures [FS] are convulsions brought on by a fever in infants or small children. Most common age group affected is between 6 months to 60 months. Studies showed that there is a variable association between febrile seizures and iron deficiency anaemia [IDA] in children. This study compared various haematological indices with febrile seizures to detect iron deficiency anaemia among children.

\section{METHODS}

This is a comparative observational study. 200 children were recruited, among which 100 children aged between 6 months and 6 years, with febrile seizures, were taken as cases, and another 100 children in similar age group, only with fever and without seizures, were taken as controls. Various blood parameters were analysed between these two groups to detect iron deficiency.

\section{RESULTS}

Haematological parameters like $\mathrm{Hb} \%$ and serum ferritin were significantly lower, and RDW was significantly increased in cases as compared to controls. This signifies a definite correlation between iron deficiency and febrile seizures.

\section{CONCLUSIONS}

There is a strong association between children with FS and iron deficiency anaemia. This suggests that IDA maybe be a risk factor for FS and all children with FS require iron indices and iron supplementation.

HOW TO CITE THIS ARTICLE: Subbarao P, Apoorva PS, Ramanan PV. To evaluate the relationship between iron deficiency and febrile seizures. J. Evolution Med. Dent. Sci. 2019;8(14):1117-1119, DOI: 10.14260/jemds/2019/247

\section{BACKGROUND}

Febrile seizure [FS] is most common in children with an incidence of $3-4 \%$ under the age of 5 years ${ }^{1}$. Most of the studies suggested that iron deficiency is a predisposing factor for febrile seizures. ${ }^{2}$ FS episodes are excruciating to the parent and child and can cause psychological trauma to the both. The relationship between fever and convulsion in children had been documented by Hippocrates as early as the $5^{\text {th }}$ century B.C, but it was not noticed as a separate clinical entity till $1980.3,4$

A Febrile Seizure is defined by the International League Against Epilepsy (ILAE) as a "Seizure occurring in childhood after 1 month of age associated with a febrile illness not caused by an infection of central nervous system, without previous neonatal seizure or a previous unprovoked seizure and not meeting the criteria for other acute symptomatic seizure". 5

Iron deficiency anaemia, as the most common type of anaemia during infancy and childhood, occurs usually

'Financial or Other Competing Interest': None.

Submission 02-03-2019, Peer Review 26-03-2019,

Acceptance 29-03-2019, Published 08-04-2019.

Corresponding Author:

Puttagunta Sree Apoorva,

D/o. Puttagunta Venkata Ramana,

5-80-2, Sreenivasam $3^{\text {rd }}$ Floor,

Ashoknagar $1^{\text {st }}$ Lane,

Guntur-522002,

Andhra Pradesh, India.

E-mail: a18appu92@gmail.com

DOI: $10.14260 /$ jemds $/ 2019 / 247$ between 9-24 months of age and this period matches with febrile seizure period6. Iron deficiency [ID] reduces the metabolism of some neurotransmitters, such as mono amine and aldehyde oxidase 7,8 . In India as per NFHS-3 70\% of under-fives are anaemic.

Many studies have highlighted the correlation between iron deficiency and febrile seizures in children. While some studies have shown that iron deficiency children will increase the seizure threshold, others suggest that iron deficiency will decrease the threshold in children.

Hence this comparative observational study was carried out to evaluate the association, if any, between iron deficiency and febrile seizures.

\section{METHODS}

Children with febrile seizures as inpatients, in tertiary care centre were enrolled in the study between November 2012 to April 2014. Sample size was taken based on period sample. A total of 200 cases between 6 months and 5 years of age with febrile seizures were enrolled and 200 children were selected who got admitted in the hospital for febrile illness but without seizures. Controls were grouped -cases and controls were matched on age basis [Within 1 month for children younger than 1 year, and 2 months children older than 1 year]. An informed verbal consent was obtained from parents or legal guardians.

Children with history of afebrile seizures, central nervous system infection, developmental delay and neurological deficit were excluded. 
A predesigned proforma was used to collect relevant information. Blood samples were collected from both cases and controls and estimated for iron deficiency. RBC indices and haemoglobin estimation were detected. Serum ferritin was measured by chemiluminescent method. Statistical data was analysed using SPSS package and Z-test was used for checking the significance with $\mathrm{P}<0.05$ considered as statistically significant. Iron deficiency anaemia was defined as $\mathrm{HB}<11 \mathrm{gm} / \mathrm{dl}, \mathrm{MCV}<70 \mathrm{fl}, \mathrm{MCH}<23 \mathrm{pg}$, ferritin $<7$, RDW $>14.5 \%$. In case of fever a higher cut-off value of ferritin between 7.1- 40 was considered as Iron deficiency anaemia.

\section{RESULTS}

Among total of 200 children, 100 were cases with febrile seizure and other 100 were controls. The mean age in months was 23.2 among cases and 23.8 among controls. The mean maximum temperature recorded was $101 \mathrm{~F}$ among cases and $101.12 \mathrm{~F}$ among the control group. With regards to family history of febrile seizures, 29 had positive family history among cases and 29 had past history of febrile seizures.

\begin{tabular}{|c|c|c|c|}
\hline Demographic Details & & $\begin{array}{c}\text { Febrile } \\
\text { Seizures } \\
\text { Cases } \\
{[\mathbf{N}=100]}\end{array}$ & $\begin{array}{l}\text { Controls } \\
{[\mathrm{N}=100]}\end{array}$ \\
\hline Mean Age [Months] & & 23.2 & 23.8 \\
\hline $\begin{array}{l}\text { Mean Maximum } \\
\text { Temperature }[\mathrm{F}]\end{array}$ & & 101 & 101.12 \\
\hline $\begin{array}{l}\text { Mean Duration of } \\
\text { Fever [Days] }\end{array}$ & & 1.65 & 3.24 \\
\hline $\begin{array}{c}\text { Family H/O Febrile } \\
\text { Seizures }\end{array}$ & $\begin{array}{l}\text { Yes } \\
\text { No }\end{array}$ & $\begin{array}{l}29 \\
71\end{array}$ & $\begin{array}{c}0 \\
100\end{array}$ \\
\hline $\begin{array}{c}\text { Febrile Seizures Past } \\
\text { H/O }\end{array}$ & $\begin{array}{l}\text { Yes } \\
\text { No }\end{array}$ & $\begin{array}{l}29 \\
71\end{array}$ & $\begin{array}{c}0 \\
100\end{array}$ \\
\hline Gender & $\begin{array}{c}\text { Male } \\
\text { Female }\end{array}$ & $\begin{array}{l}68 \\
32 \\
\end{array}$ & $\begin{array}{l}63 \\
37\end{array}$ \\
\hline $\begin{array}{l}\text { Nutritional } \\
\text { Status }\end{array}$ & $\begin{array}{c}\text { Normal } \\
\text { Malnutrition- } \\
\text { Grade -1 } \\
\text { Grade -2 } \\
\text { Grade -3 }\end{array}$ & $\begin{array}{c}85 \\
\\
11 \\
2 \\
2\end{array}$ & $\begin{array}{c}82 \\
\\
15 \\
3 \\
0\end{array}$ \\
\hline \multicolumn{4}{|c|}{ Underlying Cause of Illness } \\
\hline Acute Dysentery & & 1 & 1 \\
\hline Age & & 29 & 39 \\
\hline LRI & & 4 & 16 \\
\hline URTI & & 13 & 20 \\
\hline UTI & & 6 & 3 \\
\hline \multicolumn{4}{|c|}{ Table 1} \\
\hline
\end{tabular}

Two children among the cases group had grade -3 malnutrition. Whereas 11 had grade 1-2 malnutrition among cases and 18 among controls had malnutrition. The disease causing the fever in both groups were Acute gastroenteritis, URTI and LRI.

\begin{tabular}{|c|c|c|c|c|c|}
\hline Blood Indices & \multicolumn{2}{|c|}{ Cases [N=100] } & \multicolumn{2}{c|}{$\begin{array}{c}\text { Controls } \\
{[\mathbf{N = 1 0 0 ]}}\end{array}$} & p Value \\
\hline & Mean & SD & Mean & SD & \\
\hline HB\% & 10.92 & 1.27 & 11.31 & 1.46 & 0.032 \\
\hline MCV & 73.19 & 4.60 & 73.84 & 3.57 & 0.120 \\
\hline MCH & 22.44 & 1.74 & 22.68 & 1.52 & 0.506 \\
\hline RDW & 14.38 & 1.09 & 13.73 & 0.85 & 0.000 \\
\hline Ferritin & 45.35 & 26.71 & 82.13 & 25.05 & 0.000 \\
\hline \multicolumn{7}{|c|}{ Table 2 } \\
\hline
\end{tabular}

Haematological parameters including $\mathrm{HB}, \mathrm{MCV}, \mathrm{MCH}$, RDW and Ferritin were measured among cases and controls. The mean and SD values of $\mathrm{Hb} \%$, Ferritin was found to be less among cases when compared to controls. The difference between cases and controls was statistically significant [ $\mathrm{p}<0.05$ ] among the parameters HB\%, RDW and Ferritin.

\begin{tabular}{|c|c|c|c|c|c|}
\hline Blood Indices & Cases & $\mathbf{\%}$ & Controls & $\mathbf{\%}$ & $\mathbf{p ~ V a l u e ~}$ \\
\hline $\mathrm{HB}<11$ & 51 & $51 \%$ & 33 & $33 \%$ & 0.010 \\
\hline $\mathrm{MCV}<70$ & 32 & $32 \%$ & 17 & $17 \%$ & 0.014 \\
\hline $\mathrm{MCH}<23$ & 62 & $62 \%$ & 60 & $60 \%$ & 0.772 \\
\hline Ferritin $<7$ & 1 & $1 \%$ & 0 & $0 \%$ & 0.316 \\
Ferritin $>7.1-40$ & 43 & $43 \%$ & 4 & $4 \%$ & 0.000 \\
\hline RDW $>14.5 \%$ & 41 & $41 \%$ & 13 & $13 \%$ & 0.000 \\
\hline \multicolumn{7}{|c|}{ Table 3 } \\
\hline
\end{tabular}

The total number of children with low levels of haematological parameters are measured separately. $\mathrm{Hb} \%$ less than $11 \mathrm{gm} \%$ in $55 \%$ of the cases and only 33\% among controls. MCV was less than 70 among $32 \%$ cases and $17 \%$ controls. $62 \%$ of the cases and $60 \%$ of the controls had MCH less than 23. Serum ferritin was less than 7 in only one case and less than 40 among 43 cases and 4 controls. RDW $>14.5 \%$ among $41 \%$ cases and $13 \%$ controls. The differences between cases and controls was statistically significant among $\mathrm{Hb} \%$, MCV, Ferritin between 7.1-40 and RDW values.

\section{DISCUSSION}

In this study, $68 \%$ of the children among the FS group were males and almost similar $63 \%$ of the children among controls were males. The mean age in months was 23.2 months among cases and 23.8 months among controls. Acute Gastroenteritis was found to be the most common underlying cause among cases and controls. The mean duration of fever was 1.65 days among cases and 3.24 days in controls, which is significantly less. The obvious explanation for this is that unless there are complications like seizures, children with fever are usually evaluated and treated on an outpatient basis. Increase in brain temperature may alter neuronal function and ion channels.9,10 This might have influenced neuronal firing and probability of generating massive synchronised neuronal activity i.e. seizures. Fever, in addition to increase in brain temperature, also leads to inflammatory process which includes secretion of cytokines in their peripheral brain.11,12

In the present study family history of febrile seizures were noticed among $29 \%$ of the cases. Daoud AS et al ${ }^{13}$ found positive family history of seizures in $18 \%$ of his patients and Kumari PL et al ${ }^{14}$ noticed that $26 \%$ of his patients and positive family history. Family history of febrile seizures is associated with an increased risk of recurrence. 15,16

Past history of febrile seizures was noticed among 29\%. Gautam Shah et $\mathrm{al}^{17}$ noticed that $26.5 \%$ of the children had previous history of febrile seizures which is almost similar to our study.

The mean and SD values of the haematological parameters like HB\%, Ferritin values were lower among cases when compared to controls which was statistically significant. Whereas, the RDW value was high among cases compared to controls. Similar results were noticed in a study done by Chandrasekhar R.V et al 18, which showed that the mean and SD values of the haematological parameters [HB\%, Ferritin] among cases was less compared to controls which was statistically significant. Studies done by Piscane et al19 
showed results similar to our study. Furthermore, few more studies done by Naveedur et al, ${ }^{20}$ Daoud et al also stated that iron deficiency anaemia was more common among children with febrile seizures when compared with controls. This signifies a definite correlation between iron deficiency and febrile seizures. Some studies done to find the relationship between iron deficiency and febrile seizure have shown various results. In contrast to our finding, Korbinsky et al ${ }^{21}$ from North Dakota [USA], comparatively evaluated by a observational study, which includes 26 cases of febrile seizures and 25 controls. He concluded that children with febrile seizures were less likely to be iron deficient. This may be due to small sample size.

Abnormalities in brain iron metabolism, myelination, and neurotransmitter activity have been demonstrated in iron deficiency. We hypothesize that disruption of normal neurotransmitter activity, caused by iron deficiency predisposes to febrile seizure. Further work using animal models may help to elucidate the exact mechanism.

\section{CONCLUSIONS}

Iron deficiency is a definite risk factor for febrile seizures. Children with febrile seizures are 2.12 times more likely to have iron deficiency than other children of the same age group. A follow up study of patients found to be iron-deficient at the time of a first febrile seizure, to determine the incidence of subsequent febrile seizures after treatment for iron deficiency would be of great interest.

\section{Recommendations}

- All children aged between 6 months to 6 years with febrile seizures should be evaluated for iron deficiency anaemia.

- Children aged between 6 months to 6 years with iron deficiency, and family history of febrile seizures should be supplemented with iron to reduce the incidence of seizures episodes.

- In centres where no facilities are available to evaluate iron deficiency, iron supplementation should be given for all children.

\section{REFERENCES}

[1] Singhi P. Seizures and epilepsy in children - a practical guide. New Delhi: Hira SK 2008.

[2] Bidabadi E, Mashouf M. Association between iron deficiency anemia and first febrile convulsion: a case control study. Seizure 2009;18(5):347-51.

[3] Gardner JW, Dinsmore RC. Evolution of the concept of the febrile seizure as it developed in the American medical literature, 1800-1980. Journal of the History of Medicine and Allied Sciences 1995;50(3):340-63.

[4] Freeman JM. Febrile seizures: a consensus of their significance, evaluation and treatment. Pediatrics in Review 1981;2(7):211-2.

[5] Commission on Epidemiology and Prognosis, International League Against Epilepsy. Guidelines for epidemiologic studies on epilepsy. Epilepsia 1993;34(4):592-6.
[6] Glader B. Anemia of inadequate production. In: Man KR, Behrman R, Jenson H, et al. eds. Nelson textbook of paediatrics. $1^{\text {th }}$ edn. Philadelphia, USA: Saunders Elsevier 2007: p. 2014-7.

[7] Lozoff B, Beard J, Connor J, et al. Long-lasting neural and behavioral effects of iron deficiency in infancy. Nutrition Reviews 2006;64(5 Pt 2):S34-43, discussion S72-91.

[8] Parks YA, Wharton BA. Iron deficiency and the brain. Acta Paediatrica Scand Suppl 1989;361:71-7.

[9] Moser E, Mathiesen I, Andersen P. Association between brain temperature and dentate field potentials in exploring and swimming rats. Science 1993;259(5099):1324-6.

[10] Shibasaki K, Suzuki M, Mizuno A, et al. Effects of body temperature on neural activity in the hippocampus: regulation of resting membrane potentials by transient receptor potential vanilloid 4. Journal of Neuroscience 2007;27(7):1566-75.

[11] Cartmell T, Luheshi G, Rothwell NJ. Brain sites of action of endogenous interleukin-1 in the febrile response to localized inflammation in the rat. The Journal of Physiology 1999;518(Pt 2):585-94.

[12] Alheim K, Bartfai T. Interleukin-1 system: receptors, ligands and ICE in the brain and their involvement in the fever response. Annals of the New York Academy of Sciences 1998;840(1):51-8.

[13] Daoud AS, Batieha A, Abu-Ekteish F, et al. Iron status: a possible risk factor for the first febrile seizure. Epilepsia 2002;43(7):740-3.

[14] Kumari PL, Nair MK, Nair SM, et al. Iron deficiency as a risk factor for simple febrile seizures - a case control study. Indian Pediatrics 2012;49(1):17-9.

[15] Berg AT, Shinnar S, Hauser WA, et al. A prospective study of recurrent febrile seizures. New England Journal of Medicine 1992;327(16):1122-7.

[16] Verity CM, Butler NR, Golding J. Febrile convulsions in a national cohort followed up from birth. I--Prevalence and recurrence in the first five years of life. Br Med J 1985;290(6478):1307-10.

[17] Shah G, Parmar R. A study of febrile seizures in children in relation to iron deficiency anemia. Int J Contemp Pediatr 2017;4(5):1599-605.

[18] Chandrasekhar RV, Bhushan SG, Lakshmi VB. Iron deficiency as a risk factor for febrile seizures. Int J Pediatric Res 2016;3(4):269-73.

[19] Pisacane A, Sansone R, Impagliazzo N, et al. Iron deficiency anaemia and febrile convulsions: casecontrol study in children under 2 years. BMJ 1996;313(7053):343-3.

[20] Naveed-ur R, Billo AG. Association between iron deficiency anemia and febrile seizure in Dutch school children. Psediatr Perinat Epidemiol 1991;5:181-8.

[21] Kobrinsky N, Yager J, Cheang MS, et al. Does iron deficiency raise the seizure threshold? Journal of Child Neurology 1995;10(2):105-9. 